\title{
SEED-TUBER TRANSMISSION OF Spongospora subterranea
}

\author{
NILCEU R.X. DE NAZARENO ${ }^{* *}$ \& NORMA BOSCHETTO ${ }^{1 * *}$ \\ ${ }^{1}$ Instituto Agronômico do Paraná, IAPAR, Polo Regional de Pesquisa de Curitiba, Cx. Postal 2031, \\ CEP 80011-970, Curitiba, PR, e-mail: nilceu@pr.gov.br.
}

(Aceito para publicação em: 05/11/2001)

Autor para correspondência: Nilceu R. X. de Nazareno

\section{RESUMO}

Transmissão através de tubérculo semente de Spongospora subterranea

A transmissão de Spongospora subterranea através de tubérculo de batata (Solanum tuberosum) com sintomas de sarna pulverulenta foi verificada em condições de laboratório, em solo autoclavado. Tubérculos da cv Monalisa com diferentes níveis de severidade de sintomas foram capazes de transmitir o patógeno para a segunda geração de tubérculos, caracterizando a importância da qualidade sanitária para o controle dessa doença.
Potato powdery scab (PPS) caused by Spongospora subterranea (Wallr.) Lagerheim is spreading nationwide in the potato (Solanum tuberosum L.) growing areas of Brazil. Originally, a serious threat under center-pivot irrigation systems in São Paulo, PPS has now been found in most states where potatoes are grown (Zambolim, L. et al, Fitopatol. Brasileira 20:05-12, 1995). In Paraná, for example, PPS has only very recently been detected (Jaccoud Filho, D.S. et al, Fitopatol. Brasileira 24:292, 1999). The rising incidence of PPS is of great concern because it causes damage to the tuber's surface that prevents the use for commercial purposes.

With the increment of international trading and international commerce agreements, the phytosanitary quality of seed stocks became a very important issue. Potato production in Brazil is still dependent on seed tuber importation, and the Ministry of Agriculture's Phytosanitary Standards (MAPS) for potatoes are outdated for some diseases. The three scabs [Common - Streptomyces scabies (Thaxt.) Waks. \& Henr., Silver - Helminthosporium solani Dur. \& Mont., and Powdery Scabs] are still taken as one disease, as far as incidence is concerned. Moreover, the current standards for indicating the presence of scab are a cut point of $1 / 8^{\text {th }}$ or more of the tuber's symptomatic surface; below this, no disease incidence is present. This experiment was performed to check whether tubers with different PPS severities would transmit the $S$. subterranea to daughter tubers, in sterilized soil, under lab conditions, from January to March, 1999.

Ten potato tubers of the cv. Monalisa with PPS lesions, covering from less than $1 / 8^{\text {th }}$ to more than $1 / 2$ of the tuber surface were individually planted in $3-\mathrm{kg}$ capacity plastic pots. Two of the ten were symptomatic tubers. Pots were filled with $1 \mathrm{~h}$ autoclaved soil. After planting, pots were kept on lab benches

\footnotetext{
* Bolsista do CNPq

** Acadêmica de Agronomia da Universidade Federal do Paraná, bolsista PIBIC/ IAPAR
}

and regularly watered with sterilized distilled water to keep the soil moist in order to favour the disease cycle.

After tuber setting, plants were uprooted to check for the presence of PPS symptoms and signs of the pathogen under microscopic analysis. Three tubers, originally with high severity values, were rotted by other causes, giving birth to less vigorous plants than those from healthy tubers; they did not produce any tubers. Two out of five plants had PPS symptoms (Figure 1 ), but not all tubers of an infected plant had lesions. The presence of cistosores and swarming of zoospores (Merz, U., Plant Pathol. 46:670-674, 1997) in the infected daughter tuber lesions were observed, confirming the pathogen. Plants of the two symptomatic tubers did not produce tubers with PPS symptoms.

This preliminary experiment shows the importance of healthy seed tubers with regard to PPS transmission and pathogen introduction into uninfested soils, suggesting the need for reviewing the MAPS, at least for discriminating the scab diseases into the three known to occur in Brazil.

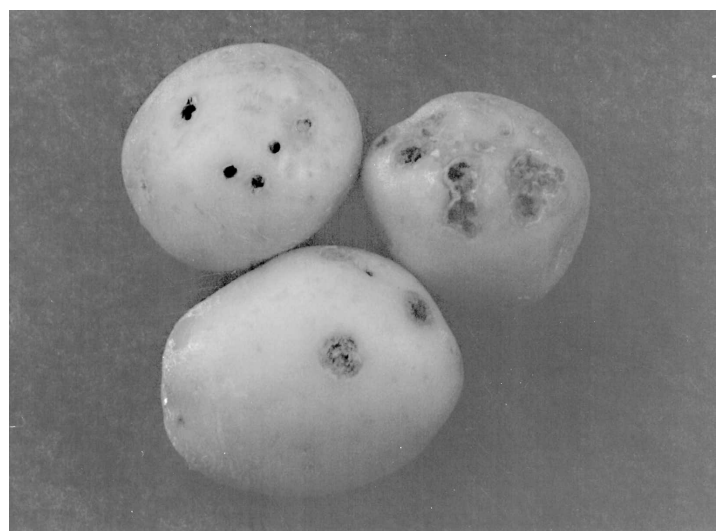

FIG. 1 - Potato (Solanum tuberosum) tubers with Powdery Scab symptoms caused by Spongospora subterranea transmitted by infested mother tubers, under laboratory, autoclaved soil conditions. 